\title{
Evaluation of therapeutic efficacy of oxytetracycline against caprine respiratory mycoplasmosis using clinical score card method" $^{\#}$
}

\author{
K. S. Sumith*1, C. G. Umesh², Chintu Ravishankar³, \\ (iD) (iD) \\ K. Mathew Manju ${ }^{4}$ and S. Ajithkumar \\ Department of Veterinary Clinical Medicine, Ethics and Jurisprudence \\ College of Veterinary and Animal Sciences, Pookode - 673576 \\ Kerala Veterinary and Animal Sciences University, Kerala, India.
}

Citation: Sumith, K.S., Umesh, C.G., Chintu Ravishankar, Mathew Manju, K. and Ajithkumar, S.2021. Evaluation of therapeutic efficacy of oxytetracycline against caprine respiratory mycoplasmosis using clinical score card method. J. Vet. Anim. Sci. 52(4): 331-334

DOI: https://doi.org/10.51966/jvas.2021.52.4.331-334

\begin{abstract}
Mycoplasmosis in goats is one of the challenging and continuous threats to small ruminant farming causing huge economic losses. This study was carried out to evaluate the therapeutic efficacy of oxytetracycline against caprine respiratory mycoplasmosis. Nasal swabs collected from fourteen goats showing clinical signs like cough, nasal discharge and abnormal breath sounds were screened for the presence of Mycoplasma spp. by polymerase chain reaction. The severity of the disease as well as the clinical improvement was recorded using a clinical score card. Oxytetracycline was administered intravenously at $15 \mathrm{mg} / \mathrm{kg} /$ day for 5 days along with supportive medications. Significant reduction in clinical score was observed after treatment and complete recovery was attained in 62.5 per cent animals.
\end{abstract}

Keywords: Mycoplasma, Oxytetracycline, Goat

Running title: Therapeutic efficacy of oxytetracycline against caprine respiratory mycoplasmosis

Mycoplasma spp. are small, cell-wall less bacteria and they have been implicated to cause various diseases in goats, especially respiratory diseases (Razin, 1992). The practise of rearing goats in groups, their tendency to huddle and stressors like adverse weather conditions predispose them to respiratory mycoplasmosis. The mortality and morbidity associated with

"Part of M.V.Sc. thesis submitted by the first author to Kerala Veterinary and Animal Sciences University, Pookode, Wayanad, Kerala

1. M.V.Sc. scholar

2. Assistant Professor

3. Associate Professor, Dept. of Veterinary Microbiology

4. Assistant Professor

5. Professor and Head

${ }^{*}$ Corresponding author: sumith.s.k.s.07@gmail.com, Ph: 8714384881

Copyright: (C) 2021 Sumith et al. This is an open access article distributed under the terms of the Creative Commons Attribution 4.0 International License (http://creativecommons.org/licenses/by/4.0/), which permits unrestricted use, distribution, and reproduction in any medium, provided the original author and source are credited. 
pneumonia due to Mycoplasma spp. have caused huge economic loss to goat-keepers all around the world. The fastidious nature of the organism makes it difficult for in vitro isolation and cultivation. For rapid diagnosis of mycoplasmosis, molecular techniques like Polymerase Chain Reaction (PCR) can be used. Treatment of mycoplasmosis mainly involves macrolide antibiotics or tetracyclines.

\section{Materials and methods}

Fourteen goats presented to Teaching Veterinary Clinical Complex, College of Veterinary and Animal Sciences, Pookode, with clinical signs like cough, nasal discharge and abnormal breath sounds were selected for the study. All the animals in the study group were subjected to physical and clinical examination after collecting detailed signalment and anamnesis. The assessment of severity of clinical condition associated with caprine respiratory mycoplasmosis was performed using a clinical score card prepared by Love et al. (2014) and modified by Gupta (2015). Score card was prepared in such a way that scores from 0 to 3 were assigned to the progressive variants of clinical signs like cough, nasal discharge, respiratory distress and ocular discharge. The scores obtained for each sign were added up to get the final score for a particular animal. The clinical assessment of the final score was carried out as per the interpretations attached which varies from healthy to severe illness (Table 1).
Nasal swabs were collected and kept in $0.5 \mathrm{~mL}$ sterile normal saline for DNA extraction. PCR was performed using primers specific for 16S rRNA of Mycoplasma spp. (Botes et al., 2015). Goats positive for Mycoplasma spp. by PCR were treated using intravenous injection of Oxytetracycline @ $15 \mathrm{mg} / \mathrm{kg} /$ day (mixed in equal quantity of Normal Saline). Supportive therapy included Flunixine meglumine @ $1.1 \mathrm{mg} / \mathrm{kg} /$ day intramuscularly, Chlorpheniramine maleate @ $0.5 \mathrm{mg} / \mathrm{kg} /$ day intramuscularly and inhalation with Tr. Benzoin @ $10 \mathrm{~mL} / \mathrm{L}$ of hot water twice daily. All the treatments were continued for five days. Comparison of clinical scores before and after treatment was done using Wilcoxon Signed Rank Test (Rangaswamy, 1995).

\section{Results and discussion}

In the present study, Mycoplasma spp. was detected in 71.4 per cent (10 out of 14) of goat nasal swabs tested by PCR. Among the goats with respiratory mycoplasmosis five (50 per cent) had mild illness, three (30 per cent) had moderate illness and two (20 per cent) had severe illness. On the completion of treatment, complete recovery was observed in seven out of ten goats (70 per cent) animals. Of the three animals that did not recover fully, two had mild illness with slight respiratory distress, small amount of watery nasal discharge and single cough when induced and the other had small amount of watery nasal discharge and single cough when induced. On statistical analysis, significant reduction in

Table 1. Clinical score card for assessment of severity of clinical condition associated with caprine respiratory mycoplasmosis.

\begin{tabular}{|c|c|c|c|c|c|}
\hline \multirow{3}{*}{ 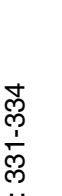 } & \multirow{2}{*}{$\begin{array}{l}\text { Clinical } \\
\text { condition }\end{array}$} & \multicolumn{4}{|c|}{ Score } \\
\hline & & 0 & 1 & 2 & 3 \\
\hline & Cough & None & Single induced & Multiple induced & $\begin{array}{c}\text { Multiple } \\
\text { spontaneous }\end{array}$ \\
\hline & $\begin{array}{l}\text { Nasal } \\
\text { discharge }\end{array}$ & None & $\begin{array}{c}\text { Small amount of } \\
\text { unilateral/bilateral } \\
\text { watery discharge }\end{array}$ & $\begin{array}{l}\text { Unilateral/bilateral } \\
\text { cloudy or excessive } \\
\text { mucus discharge }\end{array}$ & $\begin{array}{c}\text { Copious bilateral } \\
\text { mucopurulent } \\
\text { discharge }\end{array}$ \\
\hline & $\begin{array}{l}\text { Respiratory } \\
\text { distress }\end{array}$ & None & Mild & Moderate & Severe \\
\hline & $\begin{array}{c}\text { Ocular } \\
\text { discharge }\end{array}$ & None & Small amount & Moderate & Heavy \\
\hline & \multicolumn{5}{|c|}{$\begin{array}{l}\text { Interpretations } \\
\qquad 0=\text { Healthy, 1-4 = Mild illness, 5-8 = Moderate illness, 9-12 = Severe illness }\end{array}$} \\
\hline
\end{tabular}


Table 2. Comparison of clinical scores before and after treatment

\begin{tabular}{|c|c|c|c|c|}
\hline SI. No. & $\begin{array}{c}\text { Clinical score before } \\
\text { treatment }\end{array}$ & Severity of disease & $\begin{array}{c}\text { Clinical score } \\
\text { after treatment }\end{array}$ & $\begin{array}{c}\text { Z value } \\
\text { (P-value) }\end{array}$ \\
\hline 1 & 2 & Mild & 0 \\
\hline 2 & 2 & Mild & 0 \\
\hline 3 & 3 & Mild & 0 \\
\hline 4 & 5 & Moderate & 0 \\
\hline 5 & 7 & Moderate & 0 \\
\hline 6 & 4 & Mild & 0 \\
\hline 7 & 3 & Mild & 0 \\
\hline 8 & 9 & Severe & 3 \\
\hline 9 & 9 & Severe & 3 \\
\hline 10 & 8 & Moderate & 2 \\
\hline
\end{tabular}

** Significant at 0.01 level

clinical scores were observed after the therapy (Table 2). Complete recovery was observed in 70 per cent goats. Hence, oxytetracycline can be used as the effective treatment regimen for Caprine respiratory mycoplasmosis. Tetracyclines generally act as bacteriostatic antibiotics and inhibit protein synthesis by reversibly binding to $30 \mathrm{~S}$ ribosomal subunits of susceptible organisms, preventing binding to those ribosomes of aminoacyl transfer-RNA (Plumb, 2018). Recent studies have shown that oxytetracycline have additional mechanisms of action including antioxidant, anti-inflammatory and immunosuppressive activity (Olszewska, 2006). Moreover, the broad spectrum activity of oxytetracyclinemusthave effectivelyneutralised any concurrent secondary bacterial infection associated with mycoplasmosis. Giadinis et al. (2008) reported that oxytetracycline was highly effective in reducing mortality and morbidity associated with caprine respiratory mycoplasmosis. This finding is comparable to the results of the present study. Use of antiinflammatory, anti-pyretic, analgesic and antiallergic drugs along with anti-microbials helps in reducing severity of mycoplasmosis and facilitates early recovery (Yatoo et al., 2018).

\section{Conclusion}

Based on the results of the study, it can be concluded that oxytetracycline can be used to effectively treat caprine respiratory mycoplasmosis. Since recent studies have shown that oxytetracycline has additional mechanisms of action including antioxidant, anti-inflammatory and immunosuppressive activity, they can be used in reducing severity of the disease.

\section{Acknowledgements}

The authors thank the Dean, College of Veterinary and Animal Sciences, Pookode for providing facilities for conduct of the study.

\section{Conflict of interest}

The authors declare that they have no conflict of interest.

\section{References}

Botes, A., Peyrot, B.M., Olivier, A.J., Burger, W.P. and Bellstedt, D.U. 2005. Identification of three novel Mycoplasma species from ostriches in South Africa. Vet. Microbiol. 111: 159-169.

Giadinis, N.D., Petridou, E.J., Sofianidis, G., Filioussis, G., Psychas, V., Hatzopoulou, E. and Karatzias, H. 2008. Mortality in adult goats attributed to Mycoplasma capricolum subspecies capricolum. Vet. Rec. 163: 278- 279.

Gupta, D. K. 2015. Molecular diagnosis and therapeutic strategies against contagious caprine pleuropneumonia in goats. $P h D$ thesis, Nanaji Deshmukh Veterinary Science University, Jabalpur, $70 p$. 
Love, W.J., Lehenbauer, T.W., Kass, P.H., Van Eenennaam, A.L. and Aly, S.S. 2014. Development of a novel clinical scoring system for on-farm diagnosis of bovine respiratory disease in pre-weaned dairy calves. Peer J. 2: e238.

Olszewska, M. 2006. Oxytetracycline-mechanism of action and application in skin diseases. Wiadomosci Lek. (Warsaw, Poland: 1960). 59: 829-833.

Plumb, D.C. 2018. Plumb's Veterinary Drug Handbook. ( $9^{\text {th }}$ Ed.). John Wiley \& Sons. $1456 p$.
Rangaswamy, R. 1995. A textbook of agricultural statistics. (1 ${ }^{\text {st }}$ Ed.). New Age International Pvt. Ltd. New Delhi, 496p.

Razin, S.H.M.U.E.L. 1992. Mycoplasma taxonomy and ecology. American society for microbiology, Washington, DC, USA, 3-22.

Yatoo, M.I., Parray, O.R., Mir, M.S., Qureshi, S., Amin, Z., Kashoo, M.N., Fazili, M.U.R., Tufani, N.A., Singh, M., Kanwar, S.C. and Dhama, K. 2018. Mycoplasmosis in small ruminants in India: A review. J. Exp. Biol. 6: 1-18. 